Central Washington University

ScholarWorks@CWU

$3-6-2018$

\title{
Naps and Sleep Deprivation: Why Academic Libraries Should Consider Adding Nap Stations to their Services for Students
}

\author{
Mary Wise \\ Central Washington University, mary.wise@cwu.edu
}

Follow this and additional works at: https://digitalcommons.cwu.edu/libraryfac

Part of the Community Health Commons, Library and Information Science Commons, and the Public Health Commons

\section{Recommended Citation}

Wise, M. (2018). Naps and Sleep Deprivation: Why Academic Libraries Should Consider Adding Nap Stations to their Services for Students. New Review of Academic Librarianship, 24(2), 192-210. https://doi.org/10.1080/13614533.2018.1431948

This Article is brought to you for free and open access by the James E. Brooks Library at ScholarWorks@CWU. It has been accepted for inclusion in Library Scholarship by an authorized administrator of ScholarWorks@CWU. For more information, please contact scholarworks@cwu.edu. 
Naps and Sleep Deprivation: Why Academic Libraries Should Consider Adding Nap Stations to Their Services for Students

MARY J. WISE

James E. Brooks Library, Central Washington University, Ellensburg, Washington, USA

\begin{abstract}
Since the invention of artificial light, people have been working, studying and playing for longer hours than ever before. They are also sleeping less as a result. This article examines the impact of sleep deprivation on people generally, and specifically on college students. Students accrue a large sleep debt that impairs their ability to function adequately. Students suffering from sleep deprivation can be as impaired as if they are drunk. They suffer damage to their minds and bodies. Adequate sleep can repair this damage, but with the many demands on college students, they may be unlikely to be able to accomplish this. Studies have indicated that naps are beneficial in helping to reduce students' sleep debts. Universities are realizing the importance of naps, and university libraries may be ideal locations for napping stations. Several options of providing students with safe comfortable napping areas are discussed.
\end{abstract}

Keywords: Naps, sleep deprivation, college students, sleep debt, napping areas

Sleep has always been a mysterious and sometimes elusive part of life. Before the turn of the $20^{\text {th }}$ century, people customarily went to bed when it got dark, woke up when it was light, and took naps in the middle of the day if they were tired (Kryger, 2017; Wolf-Meyer, 2013). According to Mednick and Ehrman (2006), people often slept for 10 hours during the night. The invention and ensuing widespread use of the electric light bulb enabled people to extend the number of hours of light, while reducing the number of hours of darkness. The average amount of sleep on weekdays is now 6.7 hours (Coren, 1996). How can academic libraries help students get an amount of sleep that approaches what they need to function productively? Adequate sleep is an important factor in students' well-being, which in turn contributes to their academic success.

\title{
Libraries Supporting the Well-being of Students
}




\section{NAPS AND SLEEP DEPRIVATION}

The importance of student well-being has become a high priority for many universities in recent years. Libraries contribute to this goal by offering a variety of services. In addition to the traditional services of providing materials, resources, and research assistance, university libraries increasingly are providing innovative services that help students connect with the library and help reduce the stress and frustrations that are inherent in the college experience. S. Bell (2008) points out that university libraries help contribute to student retention. Libraries can also contribute to students' general well-being (Brewerton \& Hemp, 2016; Goretzki \& Zysk, 2017; Newton, 2011).

Many university libraries are introducing and continuing activities to help students fit in, feel comfortable, and have a positive college experience. SUNY Potsdam's Crumb Library began StressBusters during finals, when the library provides students with games, puzzles, coloring pages, a tiny bowling alley, a putting green, a sand box, coffee, tea, and cookies (Newton, 2011). After receiving much positive feedback about StressBusters, the library decided to continue a couple of the games throughout the semester, for anytime stress relief. The William T. Young Library, at the University of Kentucky (Wasielewski, 2009), provided first year students with pizza, soft drinks, dance lessons, a photo booth, and other activities designed to make the students feel comfortable in the library. During finals week at Niagara College, "Students can color, practice golf shots on a putting green, build with Legos and play video games” (M. Z., 2016, p. 18).

Implementation of anxiety reducing activities in libraries has surfaced in a variety of common and creative forms. Chant (2014b) discusses a graduate student at the University of Oklahoma who installed a device in the library that projects a labyrinth pattern on the floor. He reports that after using the projected labyrinth, people reported feeling more relaxed. Several 


\section{NAPS AND SLEEP DEPRIVATION}

cultures have used the practice of following a labyrinth as an aid to meditation and mental focus (Peel, 2004). According to Zucker, Choi, Cook, and Croft (2016), labyrinth walking has been beneficial to the reduction of stress.

Goretzki and Zysk (2017) cite several studies that demonstrate mindfulness practice can manage stress and increase feelings of well-being, in addition to its original goal of improving focus and positive learning techniques.

One aspect of overall student well-being at universities is helping students to feel welcome, included, and comfortable being in the academic community. Libraries can assist in those goals by providing activities and programs that keep students engaged with the university community. Such activities, according to Jalongo and McDevitt (2015, p. 255), include "mystery orientations, games, food, expos, and parties." They go on to explain that a successful and relatively inexpensive activity is that of bringing therapy dogs to the library. Indiana University of Pennsylvania Libraries instituted a program of visiting therapy dogs during finals. After sessions with the therapy dogs, students reported feeling less stressed.

Brewerton and Woolley (2016) discuss activities at The Library of the University of Warwick library that help facilitate well-being among their students. They believe that the library should be supporting the higher portions of Maslow's Hierarchy of Need. The library staff offer a program called Study Happy. This program provides students with activities that guides them to "connect, be active, take notice, keep learning, give" (Brewerton \& Woolley, 2016, p. 20).

Activities that foster these steps include crafts, such as coloring and origami, ukulele lessons, yoga, games puzzles, a tea party, and celebrations such as World Book Day. They also give a stress toy, in this case a penguin called Kirby, to students who seem to enjoy taking it with them on outings for photo sessions. They also provide food at weekly gatherings. Their most 


\section{NAPS AND SLEEP DEPRIVATION}

popular Study Happy activity, however, has been the therapy dog sessions, called Pets as Therapy (PAT). As is the case at other universities that offer this activity, the students respond that interacting with the dogs has helped them with stress and improved their moods.

Therapy dog programs seem to be favorite stress relieving activities at several university libraries. The University of Connecticut Homer Babbidge Library, the Gerstein Science Information Centre on the campus of the University of St. George, Toronto, The University of Buffalo Health Sciences Library, and several other academic libraries provide therapy dog activities (Reynolds \& Rabschutz, 2011; A. Bell, 2013; Lannon \& Harrison, 2015; Daneman, 2013; Mawhinney, 2011; Katz, 2016). These therapy dog programs are particularly successful during finals. The libraries receive considerable positive feedback from students, who report reduction in their stress levels. There are many recognized benefits of therapy dog activities, and most libraries plan to continue their programs. At Whitworth College, the library offers kittens to pet and free coffee during finals as de-stressors (Robinson \& Clark, 2015).

At the author's own library, finals week destressing activities include button making, coloring pages, Waffle Night, and a therapy dog program (Central Washington University Brooks Library, n.d.).

While students at all these libraries have self-reported the benefits of the provided activities on their stress levels, few academic libraries are providing help to students to combat one of their major stress creators - sleep deprivation.

\section{Circadian Rhythm and Sleep Cycles}

What is sleep deprivation and why is it so dangerous? To understand sleep deprivation, people need to understand how sleep works. It sounds simple, but there is a lot more to it than it 


\section{NAPS AND SLEEP DEPRIVATION}

seems. When and how long people sleep is determined by circadian rhythms. These are the biological clocks that tell people's bodies when to do certain things throughout the day. People's circadian clocks are based around the 24-hour day.

The part of the circadian rhythm that regulates sleep releases melatonin at approximately 9:00 p.m., so when bedtime arrives, people are sleepy enough to go to sleep. The deepest sleep time occurs between 2:00-4:00 a.m. The body stops producing melatonin around 7:30 a.m., so people naturally wake up around that time.

Sleepers rotate through several sleep stages, with each stage performing a unique function. People may go through 3-4 cycles of stages each night during sleep (Mednick \& Ehrman, 2006).

Stage 1 is also known as the hypnogogic state. It can be experienced through the feeling of being not quite asleep, but not quite awake, either. People may experience short, unreal images or dreamlike occurrences. Stage 1 only lasts for about five minutes or so.

Stage 2 is characterized by episodes of sleep spindles. These spindle shaped spikes are documented through electroencephalogram (EEG) readings, and are known also as K complexes. This is a light sleep stage. The benefits of Stage 2 sleep are that it increases alertness and reinforces motor and muscle learning skills, such as dancing, driving, and physical tasks. Stage 2 lasts about 20 minutes.

Slow Wave Sleep (SWS) is the next stage (previously known as Stages 3 and 4) (Kryger, 2017). This is the deep sleep stage. It is very difficult to awaken someone from SWS. Benefits of SWS are that it restores physical damage or stress to bones, muscles, tissues, and organs, and reduces stress and anxiety. It metabolizes fats and carbohydrates, and fortifies the immune 


\section{NAPS AND SLEEP DEPRIVATION}

system. SWS can be of variable length, generally lasting longer during the cycles that occur early in the night.

Rapid Eye Movement (REM) is the final stage of the sleep cycle. The first REM stage of the night generally lasts about ten minutes, but normally increases over the night. REM is distinguished by the characteristic rapid eye movement of people experiencing the REM stage. REM is the dreaming stage, and the memory improvement stage. It helps ingrain information learned before going to sleep into the sleeper's memory. REM usually completes the sleep cycles after about 90 to 110 minutes (Briggs, 2015; Mednick \& Ehrman, 2006; National Institute of Neurological Disorders and Stroke, 2008; WebMD Medical Reference, 2016).

Considering the benefits of sleep, what are the consequences of sleep deprivation? People suffering from sleep deprivation accrue a sleep debt. Sleep debt is "a term characterizing the cumulative effects of sleep deprivation" (Mednick \& Ehrman, 2006, p. 134).

Research at the National Institute of Mental Health indicated that when people are given 14 hours of darkness, they tend to sleep 9-10 hours (Coren, 1996). In the study, subjects who slept 9-10 hours (versus 8 hours) were more energetic and alert. Even people who are sleeping the recommended 8 hours per night could be carrying a sleep debt. The sleep debt of someone who sleeps consistently fewer than the recommended numbers of hours per night continues to compound. Even losing a few hours per night for only a day or two can have an adverse effect on performance. Coren (1996) explains, "Losing only 4 hours of sleep in a single night can make a person's reactions 45 percent slower. Losing the equivalent of a full night of sleep can double the amount of time it takes for a person to react" (p. 73).

O'Callaghan (2016) references Charles Czeisler discussing the fact that along with quiet and temperature, the other critical factor in the quality of sleep is the length of that sleep. The 


\section{NAPS AND SLEEP DEPRIVATION}

more sleep cycles people have during the night, the longer the REM stage becomes in each subsequent cycle. If people see blue light (computer and cell phone) just before bedtime, that can delay sleep by one to one and one-half hours, so that the longest REM sleep periods will not occur, since they tend to occur in the last 2 hours or so of sleep. People who wake up (or have to wake up) before these long REM periods can occur, rob themselves of REM periods and their vital benefits. This also happens when people must wake before dawn. Czeisler recommends a clock that wakes people by gradually increasing light in the room. This can help avoid sleep inertia. Sleep inertia is that groggy, unfocused feeling everyone has experienced on occasion. It occurs when someone is awakened during slow wave sleep (Brooks \& Lack, 2006). It can last anywhere from a few minutes to several hours.

Microsleep is a dangerous "period of sleep that lasts up to a few seconds, usually experienced by people who suffer from narcolepsy or sleep deprivation" (Mednick \& Ehrman, 2006, p. 131). In a study by Poudel, Innes, Bones, Watts, and Jones (2014), 20 young adults, who were not sleep deprived, performed monotonous visuomotor tasks. The authors established that 14 of the subjects had a minimum of 36 microsleeps during the 50-minute testing period. Jonsson (2015) cites studies that indicate people are especially susceptible to microsleeps in the days after the Daylight Saving Time clock change. People have already accrued an hour of sleep debt, and they are more likely to stay up later because of longer daylight hours in the evening.

\section{Sleep Deprivation}

Sometimes people mistake the symptoms of sleep deprivation for other conditions. When people are suffering from sleep deprivation, they may think they are just overtired or fatigued. 


\section{NAPS AND SLEEP DEPRIVATION}

Mednick and Drummond (2009) clarify the difference. Fatigue makes a person too physically or mentally tired to perform a function. Sleepiness causes a person to fall asleep.

The symptoms of stress can also look a lot like the symptoms of sleep deprivation. According to Mednick and Ehrman (2006), often people who believe they are suffering from stress try various stress relief methods. These methods may not work because something other than stress is affecting these people. Working long hours is high on the list of causes for stress. Working long hours is also a major reason for not getting enough sleep. Many people who think they are suffering from high stress levels may be sleep deprived and need more sleep in order to function adequately.

Sleeping too little and going to work (or college) after little sleep is looked upon approvingly by our society (Coren, 1996). Society credits industriousness and efficiency to those who sleep few hours. However, employers (and professors) would not be pleased to see employees and students coming in drunk, yet sleep deprivation can have the same effect on performance (Hemp, 2004).

A significant negative result of sleep deprivation is drowsy driving. In "Drowsy Driving: Asleep at the Wheel" (2015), the Centers for Disease Control and Prevention report "up to 6,000 fatal crashes each year may be caused by drowsy drivers" (para. 4). The report recommends that drivers experiencing symptoms of drowsy driving should take a 15-20 minutes nap before continuing to drive.

Sleep researcher Charles Czeisler points out that most sleep deprived driving incidents happen in the middle of the afternoon because there are so many sleep-deprived drivers out during the day. He says that in monitored driving tests, $22 \%$ of crashes and near crashes are a result of people "zoning out" during the daytime (Harvard University, 2016). Czeisler says 6400 


\section{NAPS AND SLEEP DEPRIVATION}

deaths are caused each year because of sleep-deprived drivers. Sleep deprived college students are especially at risk while driving. Dement (1997) reports that 55\% of fatal accidents involving drowsy driving involve people under 25 years of age. When students drive while extremely sleepy, their reaction times and decision-making skills are comparable to those of people under the influence of alcohol (Watson et al., 2015). Carskadon (2002) describes survey results that revealed $20 \%$ of the students surveyed had fallen asleep while driving. This puts college students at high risk for injury. Sometimes drivers do not even realize that they have been asleep. Stutts, Wilkins, and Vaughn (1999) discuss studies that indicate people cannot necessarily tell how sleepy they are and how easily they might fall asleep.

Results of a study by Williams, Davies, Thiele, Davidson, and MacLean (2012) indicated that college students surveyed about driver responsibility tended to hold drunk drivers at a higher level of blame than sleep deprived drivers. They acknowledged that drunk driving was wrong, but thought that anyone could be sleepy while driving. Williams, Davies, Thiele, Davidson, and MacLean recommended an education program that advises students of the dangers of drowsy driving, similar to those for dangers of drunk driving.

Czeisler (2006) explains that sleep deprived people do not have the ability to realize how impaired they are. If someone has averaged four hours of sleep a night for several days, that person is as impaired cognitively as having been awake for 24 hours. That is enough impairment to equate to being legally drunk, the equivalent of a .1\% blood alcohol level. The Federal Motor Carrier Safety Administration (2014) provides a short quiz drivers can take to see if they are at risk for drowsy driving.

Researchers had subjects sleep only 5 hours per night for 5 days. When they were given 3 alcoholic drinks, they had a similar effect on the subjects that 6 drinks would have if they were 


\section{NAPS AND SLEEP DEPRIVATION}

normally rested (Coren, 1996). When the subjects slept 10 hours per night for 6 nights, and were given 4 alcoholic drinks, the alcohol had minimal effects on them. Mednick and Ehrman (2006) mention studies that indicate drivers who get only 6 hours of sleep are more likely to cause an accident than those who had blood alcohol levels of .05\% (over half the legal limit in many states). In fact, for each hour less of sleep, the effects are similar to taking another drink. Several other studies mention the equivalent nature of sleep deprivation to the impairment caused by alcohol consumption (Arnedt, Wilde, Munt, \& MacLean, 2001; Czeisler, 2006; Drowsy Driving Quiz, 2014). For college students learning skills and information they will use throughout their lives, this can be disastrous. Even though many students realize the importance of not driving while sleepy, they do drive because they do not seem to realize they are sleepy. Pizza et al. (2010) surveyed hundreds of students, many of whom admitted to having had automobile accidents while driving drowsy. Some of the students used various methods to try to dispel their sleepiness while driving (such as open windows, loud radios, singing, and caffeine consumption); however, only four students reported taking a nap to alleviate sleepiness.

\section{Benefits of Naps}

Several researchers have performed studies to determine what benefits, if any, naps have to sleep deprived and non-sleep deprived people. In a study by Lau, Alger, and Fishbein (2011), test subjects who napped immediately after learning and those whose naps were delayed did much better on recall and relational interpretation than did those subjects who did not nap at all after learning. There was no significant difference between the improvement of the napping groups of subjects, demonstrating that whether the nap is delayed for a time or not, learning still takes place during the naps. 


\section{NAPS AND SLEEP DEPRIVATION}

Ruch, et al. (2012) discussed several studies that demonstrated even naps as short as six minutes helped increase memory retention. Lahl, Wispel, Willigens, and Pietrowsky (2008) compared recall ability after short naps (about six minutes) and long naps (about 30 minutes). They discovered that both lengths of naps were helpful for memory recall, but the longer naps were better than the shorter ones. "Naps can be very effective at restoring performance, and if they are brief-less than a half hour-they will induce less grogginess upon awakening" (Czeisler, 2006, p. 59).

Sleep inertia is more likely to occur following long naps, because people reach the slow wave sleep (SWS) stage. The inertia can last up to 4 hours after awakening (Ye, Hutton Johnson, Keane, Manasia, \& Gregas, 2015). Sometimes people waking up from naps experience the groggy feeling caused by sleep inertia. Nappers can usually avoid this feeling by keepings naps short enough so that they do not wake up during slow wave sleep (SWS). This type of nap would be about 20 minutes long (Mednick \& Ehrman, 2006). Dhand and Sohal (2006) also recommended avoiding sleep inertia by taking naps of no more than 20 minutes or alternatively taking one of 90 minutes. This causes the napper to wake before or after SWS occurs. If a nap exceeds one sleep cycle (about 90 minutes), it is no longer a nap, but actual sleep. If it exceeds two sleep cycles (about 3 hours), the nap will begin to affect nighttime sleep. Naps taken during lunch breaks have demonstrated improvement in afternoon work performance and have helped avoid the mid-afternoon dip (Zhang, Sun, \& Liao, 2009). Results of a study by Mednick, Nakayama, and Stickgold (2003, p. 698), “... indicate that a 90-min nap can produce as much improvement as a night of sleep, and a nap followed by a night of sleep provides as much benefit as two nights of sleep." 


\section{NAPS AND SLEEP DEPRIVATION}

Brooks and Lack (2006) studied subjects taking varying lengths of naps, from five to 30 minutes. While all the subjects improved in performance and alertness during the next three hours, the authors concluded that a 10-minute nap was the most beneficial without causing sleep inertia. Taub, Tanguay, and Clarkson (1976) also found that students who napped demonstrated better task speed and mood after waking than the students who did not nap.

Although Tucker, et al. (2006) did not find that procedural memory was improved by a nap, they did find that declarative memory (ability to recall facts) was improved after a nap. Payne, et al. (2015) discovered that subjects remembered images of emotional scenes better after a nap than those who did not take the nap. Both groups remembered neutral scenes equally well. Wagner, Hallschmid, Rasch, and Born (2006) discovered that subjects who slept for three hours after reading emotional themed texts were able to recall that information for four years. Subjects who stayed awake forgot the information within three hours of learning it. Wagner and Born (2008) found no such lengthy recall when learning neutral material.

While many studies indicate naps are beneficial for healthy people, some studies indicate this may not always be the case. Many of them caution against napping too long or too late in the day. Backhaus, et al. (2016) found no difference in learning motor skills between those subjects who took short naps, long naps, or no naps.

Taking naps in the late afternoon or early evening can cause people to fall asleep later or reduce the quality of their sleep according to Buboltz, et al. (2006). They recommend that naps should not last more than one hour. Ye, Hutton Johnson, Keane, Manasia, \& Gregas (2015) also found that napping later in the afternoon or in the evening can also lead to disruption of nighttime sleep. Mednick and Drummond (2008) discuss this topic and conclude that napping 


\section{NAPS AND SLEEP DEPRIVATION}

does not disrupt the nighttime sleep of healthy people, with two exceptions - taking naps within 2-3 hours of bedtime and for night shift workers.

In spite of neutral or negative publicity, naps are very popular. They are so important to some people that there is even a National Napping Day (National Day Calendar, 2017). It is the Monday after Daylight Saving Time begins each year. There is also a National Public Sleeping Day. It takes place on February 28.

As people decide to take naps, they are also making decisions about how to structure their naps. The napper must be aware of the options and decide when and how long to nap. 20, 60 , and 90-minute naps provide varying results. De Lange (2016) suggests timing naps for particular benefit, such as 10 minutes for concentration and alertness, 20 minutes for memory enhancement.

Even with the best of intentions, college students may be unable to get enough nighttime sleep. Their sleep debts continue to increase, resulting in poorer performance and rising health issues.

Napping, whether intentional or unintentional, will occur. Unintentional napping may happen during classes or while students are working. That is bad enough, but they may also fall asleep while driving. Drowsy driving is a serious problem. Sleep deprived people experience periods of microsleep. Almost everyone who has worked at or attended a university has witnessed students slumped over tables in the library, curled up on benches, and sprawled out on lawns napping.

In 2014, the University of Michigan opened a napping station in the Shapiro Library (Chant, 2014a). It was located in a corner of the library and provided students with vinyl cots and lockers for their personal belongings. According to Draplin (2014) a few months later, the cots 


\section{NAPS AND SLEEP DEPRIVATION}

were replaced with a MetroNaps Energy Pod. This is a semi reclining elongated chair with a curved privacy shield. It plays music and gradually awakens nappers with sound, lights, and vibration. Several other universities have installed Energy Pods as well, including Washington State University. In spring 2017, the university opened their brand new Chinook Student Center (“Chinook Student Center first floor opens", 2017; Washington State University, n.d.). One of the features is the Nap Zone, which provides nap pods and recliners for sleepy students. According to Sayej (2016), napping stations are becoming more numerous in universities as well as with private companies. Several universities have installed technologically advanced pods for napping students. Others have provided anything from beanbags to cots to recliners for napping students to use. Many of the universities' nap stations are in their student centers, but several libraries are beginning to provide them as well (Wake Forest University, n.d.; University of Manchester, n.d.). Others are considering the option (O'Connell, 2016; Zielonka, 2016).

The University of East Anglia (n.d.) has the Nap Nook in its Student Union. It contains beanbags, sofas, and a closed circuit camera. In 2015, the University of Manchester installed a nap pod in the Alan Gilbert Learning Commons in the library (Cerqueira, 2015). In 2016, students at Edinburgh University voted to purchase nap pods for the library (Hunter, 2016).

Several universities that do not have dedicated napping areas give students advice on feasible napping locations around campus. University of Texas at Austin, Macalester College, University of Richmond, University of California campuses at Santa Barbara, Davis, and San Diego, University of Tulane, Harvard, and other universities provide maps of the best places to nap on campus (Healthyhorns University Health Services, 2016; Macalester College, 2017; URWell, n.d.; Health Education and Promotion, 2015; Cabrera, 2016; UCSD Student Health Advocate Program, 2011; “Tulane University nap map”, n.d.; Sewani, 2013). With students' full 


\section{NAPS AND SLEEP DEPRIVATION}

schedules and late hours, napping is necessary. Students usually discover the best napping locations on campus. Surprisingly, some universities are removing comfortable furniture from these locations in an effort to discourage students from napping (Mednick \& Ehrman, 2006).

\section{College Students and Sleep Deprivation}

American College Health Association-National College Health Assessment II (2015) reported that in a survey of more than 20,000 undergraduate college students, $91 \%$ of the students reported they felt daytime tiredness and sleepiness in the previous 7 days (American College Health Association-National College Health Assessment II, 2015, p. 16). 43.4\% of the students also reported that they had more than a little problem to a very big problem with sleepiness during daytime activities during that time.

Teenagers and young adults are especially susceptible to sleep deprivation because their circadian rhythms shift during adolescence. Their body clocks tell them to stay up later in the evening and to sleep later in the morning. Unfortunately, just when their bodies are telling them to sleep later, their schedules are forcing them to do just the opposite (Coren, 1996). They can do their best studying late at night. If they are not studying, there are other activities, such as social media, television, and music to entertain them. Even if they try to go to bed earlier, they might not be able to sleep. Their school (high school and then college) schedules force them to get up early in the morning to attend classes during which they are unable to stay awake. Coren has heard reports that as many as $40 \%$ of students are sometimes absent from early morning classes. Often the students' parents do not even understand what is happening. Teens are often accused of being irresponsible and lazy because they stay up late and want to sleep half the day away. In addition to having a later circadian rhythm shift, teens need more sleep than older adults need. 


\section{NAPS AND SLEEP DEPRIVATION}

Teens need between nine and 11 hours per night (Coren, 1996; Mednick \& Ehrman, 2006).

Dement and Vaughan (1999) make the point that teenagers are even more sleep deprived than the general population. They carry so much sleep debt that even when they get a full night's sleep, it is not enough to make up for their long-term sleep debt.

Despite needing more sleep, teens begin following the same pattern as adults, who take time away from sleeping to perform tasks that need to be completed (Coren, 1996). They are rewarded for this behavior by a society that admires industriousness at the cost of sleep and regards sleeping late as laziness.

"Various factors that contribute to the sleep problems of college students have been identified. These include stress, poor time management, poor sleep habits, and environment" (Rolston, Sandlin, J., Sandlin, M., \& Keathley, 2007, p. A-36). Gilbert and Weaver (2010) surveyed 557 undergraduate psychology students, using the Pittsburgh Sleep Quality Index (PSQI) (University of Pittsburgh University Marketing Communications Webteam, 2012) and the Goldberg Depression Inventory (GDI), (Staff, 2011), to determine the relationship between sleep quality and academic grades of college students. They determined that poor sleep quality does result in low academic performance, and that $70 \%$ of their test subjects were sleep deprived. In a study of undergraduate students, Carter, Chopak-Foss, and Punungwe (2016) administered the Pittsburgh Sleep Quality Index (PSQI). They determined that for the previous month, over $50 \%$ of the students slept less than 7 hours per night, and that only $8 \%$ of the student rated their sleep quality as very good. "In one study, researchers found a $13.3 \%$ reduction in the average sleep length among college students from 1969 (7.5 hours per night) to 1989 (6.5 hours per night), suggesting insufficient sleep has become more common in recent years" (Brown, Buboltz, \& Soper, 2006, p. 231). With that little amount of sleep, students are probably missing 


\section{NAPS AND SLEEP DEPRIVATION}

out on the sleep cycles at the end of the night, and are deprived of REM sleep, the memory improvement stage.

Another sleep disrupter is the proximity of cell phones to sleeping college students (Rice, 2011). They wake up to answer calls and text messages, even if it in the middle of the night. This can add another 45 minutes per week to their already high sleep debt.

Students sometimes think they are not sleep deprived because they do not feel sleepy. Herrmann, et al. (2010) demonstrated that people can frequently fall asleep even without feeling sleepy first. This can be dangerous to students because they have no warning that they are about to fall asleep. In Hermann's study, the subjects who were the most sleep deprived were the least likely to realize they were sleepy just before falling asleep.

A study discussed by Mednick and Ehrman (2006) revealed that students who studied all night thought they performed better on exams. However, they performed worse than students who had slept for eight hours the night before the exam. Even students with six hours of sleep who thought had performed well, had not performed as well as those with more sleep. People, including students, who are sleep deprived, do not realize they are not functioning well.

In a conference presentation, Cunningham (2007) reported about sleep debt occurring after students do not get the required amount of sleep. Universities do not generally educate students on the dangers of sleep deprivation and sleep debt. Students do not understand the results of sleep debt and try to stave off sleepiness with some type of stimulant rather than get enough sleep. Cunningham recommends that sleep hygiene be taught to students at university orientations. Some universities are making efforts to help their students get more sleep. One example is The Deerfield Academy. They delayed their school start time by 35 minutes, 


\section{NAPS AND SLEEP DEPRIVATION}

resulting in significant reductions in illness, more students taking time for breakfast, and a considerable increase in GPA (Pope, 2012).

The Edina, Minnesota district also delayed the start of the school day, resulting in higher test scores (Dement \& Vaughan, 1999). "In 1978 just 24\% of students reported sleep problems, compared with 68\% in 1992 and 71\% in 2007" (Durrant, 2015, para. 4). Durrant explains that this is a worldwide problem. Many universities are beginning classes even earlier in the morning, but the University of Oxford is offering later classes in the morning in the hopes that students' grades will improve. Despite post-adolescents needing to sleep later, most universities are not delaying early morning classes. Students who are already sleep deprived each morning will become even sleepier in the early afternoon.

For most people the urge to sleep is strongest between about 2:00-4:00 a.m. The next strongest time is between about 1:00 and 3:00 p.m. (Dement \& Vaughan, 1999). Mednick and Ehrman (2006) explain that sleep pressure is low when people awake, but rises during the day, reaching its highest point at bedtime. The tendency for Rapid Eye Movement (REM) goes in the opposite direction, being the highest in the early morning and the lowest in the late evening. When the two cross, it is during the early afternoon, from around 1:00-3:00 p.m. This is known as the mid-afternoon dip, the mid-afternoon slump, or the post-lunch dip. According to Coren (1996), studies have demonstrated that the mid-afternoon dip is not dependent on having eaten lunch. Subjects had the dip, regardless of whether they had eaten or not, or if they had eaten earlier or later. If the dip were related to meals, there would be dips after breakfast and supper, but there is no dip after those meals. People (coincidentally) have associated the dip with lunch because it occurs shortly after the usual lunchtime. Campbell (1992) also discusses studies in which subjects were sleepy in the mid-afternoon under several conditions of meal timing or no 
NAPS AND SLEEP DEPRIVATION

meals at all. The early afternoon is the time people have traditionally taken naps (Mednick \& Ehrman, 2006). The urge to nap that occurs in the early afternoon happens regardless of whether or not someone has eaten lunch, and even if the person is unaware of the time (Mednick \& Drummond, 2009; Campbell, 1992). The afternoon is prime napping time for students who are already carrying a large sleep debt. The afternoon is also a time when many students are studying at the library. Can libraries help their students combat sleep deprivation? Are napping areas feasible services for libraries to provide?

\section{Napping Services in University Libraries}

There is a lack of scholarly articles discussing the benefits of napping areas in academic libraries, or even on university campuses. This makes identification of libraries or universities providing napping stations difficult to identify. The author was able to identify only 18 universities in the United States that could be identified as having nap stations in the library or elsewhere on campus. Nine of those universities were R1 (highest research) institutions. The others were smaller universities or private universities or colleges. The author sent a link to the survey to the 18 universities or libraries via email. Questions asked were:

- Does your institution provide a napping station or area dedicated to napping for students?

- If no, does your institution provide any sort of list, guide, or suggestions for locations on campus suitable for napping?

- If yes, is it located in the library?

- If not located in the library, where is it?

- Who administers it?

- Is it still available?

- If not still available, why not?

- If yes, what does it consist of (nap pods, beanbags, lounge chairs, etc. \& how many)?

- Is it well used?

- Is there a time limit for use?

- Is its use monitored by library/university personnel?

- Is there someone I can contact if I have more questions? 


\section{NAPS AND SLEEP DEPRIVATION}

Of the eight libraries that responded, seven answered that they do have a napping station on campus. Out of those seven, four were located in the library, and three were located elsewhere on campus (near the dining hall, university center, wellness center). One responded they no longer have a nap station. The nap stations reported as current consist of a variety of furnishings: nap pods, recliners, and large beanbags. Answers about time limits and whether the areas are monitored were mixed, but most respondents reported that the napping areas are well used by the students. There did not appear to be any assessment of the service, other than self-reporting by the students. This is a library service in its infancy, and there is not much information available. Some universities provide a separate room for napping. Some use open alcoves for napping areas. Others just place comfortable furniture in quiet areas of the library.

\section{Conclusion}

Much research points to the benefits of napping. Since college students frequently are observed asleep wherever they are throughout the day, research indicates universities should consider the advantages to students of providing an area where they can nap safely and comfortably. The library seems to be ideally situated for this, since students are in the library studying when they may need to take a break, and it is usually open many hours. Literature lacks studies that demonstrate the benefits of libraries providing napping areas to students. The majority of information in that regard comes from students self-reporting the benefits. One major apparent benefit is that students who are studying in the library are not obliged to leave the building to seek a place to nap. Once they leave the library to go home or to the student center for their naps, they may be unlikely to return to the library. Depending on the physical configuration of the campus, the library may be far from the students' dorm rooms or homes. 


\section{NAPS AND SLEEP DEPRIVATION}

There may not even be another convenient location for napping on campus. Remaining in the library for their naps is of benefit to students because in leaving the library they break their continuity of studying. If they remain in the library to nap, that break is shorter, and when students resume their work, they are still located near the resources and the research assistance of library personnel. If it is nighttime or winter, students may feel safer not having to go outside of the library building until they are finished for the evening.

Napping opportunities in the library need not be as elaborate as expensive nap pods. They can be as simple as beanbags or recliners scattered throughout the library or a specific area. If university libraries are willing to provide everything from food to therapy dogs to support the well-being of their students, they should at least consider providing them with somewhere to take a quick nap and rid themselves of at least some of their sleep debt. Dement and Vaughan (1999, p. 371) assert, "Naps can make you smarter, faster and safer than you would be without them. They should be widely recognized as a powerful tool in battling fatigue, and the person who chooses to nap should be regarded as heroic.” Even though several academic libraries are beginning to give credence to the value of providing nap stations in the library, there have not been studies conducted demonstrating the benefits of providing this service. If this is to be a continuing trend, there is a need for more research in this area. In the meantime, there are only the assertions of students that nap stations located in the library are beneficial to them. Assessment of existing napping stations will assist other libraries to determine if providing them will be of benefit to their students. The job of academic libraries is to assist their students to attain their academic and personal goals. If providing napping stations will benefit their students, libraries should consider providing them. 


\section{REFERENCES}

American College Health Association-National College Health Assessment II. (2015). Undergraduate Students Reference Group Executive Summary Spring 2015. Retrieved from http://www.acha-ncha.org/

Arnedt, J. T., Wilde, G. J., Munt, P. W., \& MacLean, A. W. (2001). How do prolonged wakefulness and alcohol compare in the decrements they produce on a simulated driving task? Accident; Analysis and Prevention, 33(3), 337-344.

Backhaus, W., Braaß, H., Renné, T., Krüger, C., Gerloff, C., \& Hummel, F. C. (2016). Daytime sleep has no effect on the time course of motor sequence and visuomotor adaptation learning. Neurobiology of Learning \& Memory, 131147-154.

doi:10.1016/j.nlm.2016.03.017

Bell, A. (2013). Paws for a study break: Running an animal assisted therapy program at the Gerstein Science Information Centre. Partnership: The Canadian Journal of Library \& Information Practice \& Research, 8(1), 1-14.

Bell, S. (2008). Keeping them enrolled: How academic libraries contribute to student retention. Library Issues, 29(1), 1-4. 
NAPS AND SLEEP DEPRIVATION

Brewerton, A., \& Hemp, B. (2016). Study happy: Library wellbeing initiatives from the University of Warwick. SCONUL Focus, (68), 15-25.

Briggs, S. (2015, June 27). Why Your Students (And You) Need Daytime Naps: How Napping Can Dramatically Improve Learning \& Memory. Retrieved June 22, 2017, from http://www.opencolleges.edu.au/informed/features/napping-can-dramatically-improvelearning-memory/

Brooks, A., \& Lack, L. (2006). A brief afternoon nap following nocturnal sleep restriction: which nap duration is most recuperative? Sleep, 29(6), 831-840.

Brown, F. C., Buboltz, W. C., \& Soper, B. (2006). Development and Evaluation of the Sleep Treatment and Education Program for Students (STEPS). Journal of American College Health, 54(4), 231-237.

Brown, F. C., Soper, B., \& Buboltz Jr., W. C. (2001). Prevalence of delayed sleep phase syndrome in university students. College Student Journal, 35(3), 472.

Buboltz, W.C. Loveland, J., Jenkins, S.M., Brown, F., Soper, F., \& Hodges, J. (2006). College student sleep: Relationship to health and academic performance. In M.V. Landow (Ed.) College students: Mental health and coping strategies (pp. 1-39). New York: Nova Science. 
NAPS AND SLEEP DEPRIVATION

Cabrera, O. (2016, June 10). The official UCSB nap map. The Tab. Retrieved July 28, 2017, from https://thetab.com/us/ucsb/2016/06/10/official-ucsb-nap-map-2175

Campbell, S. S. (1992). The timing and structure of spontaneous naps. In C. Stampi (Ed.), Why we nap: Evolution, chronobiology, and functions of polyphasic and ultrashort sleep (pp. 71-81). Boston: Birkhäuser.

Carskadon, M. A. (2002). Risks of driving while sleepy in adolescents and young adults. In M. A. Carskadon (Ed.), Adolescent sleep patterns: Biological, social, and psychological influences (pp. 148-158). Cambridge: Cambridge University Press.

Carter, B., Chopak-Foss, J., \& Punungwe, F. B. (2016). An analysis of the sleep quality of undergraduate students. College Student Journal, 50(3), 315-322.

Central Washington University Brooks Library. (n.d.). Take the Next Step... Retrieved July 28, 2017, from http://www.lib.cwu.edu/Library-Past-Events

Cerqueira, M. (2015, May 11). University of Manchester unveils student sleeping pod. Retrieved July 26, 2017, from http://www.telegraph.co.uk/education/universityeducation/studentlife/11597238/University-of-Manchester-unveils-student-sleeping-pod.html 
NAPS AND SLEEP DEPRIVATION

Chant, I. (2014a). Academic: Univ. of Michigan Libraries open nap stations. Library Journal, 139(10), 20.

Chant, I. (2014b). Library Labyrinths Pave the Path to Relaxation. Library Journal, 139(11), 16.

Chinook Student Center first floor opens | WSU News | Washington State University. (2017, February 20). Retrieved June 29, 2017, from https://news.wsu.edu/2017/02/20/chinook$\underline{\text { student-center-first-floor-opens/ }}$

Coren, S. (1996). Sleep thieves: An eye-opening exploration into the science and mysteries of sleep. New York, NY: Free Press.

Cunningham, T. (2007). A new addition to college debt: Sleep debt and a new generation. American Journal of Electroneurodiagnostic Technology, 47(4), 284.

Czeisler, C. A. (2006). Sleep deficit: the performance killer. A conversation with Harvard Medical School Professor Charles A. Czeisler. Harvard Business Review, 84(10), 53.

Daneman, M. (2013, December 10). Exams got you stressed? Rover to the rescue. USA Today. Retrieved, from https://www.usatoday.com/story/news/nation/2013/12/10/dogs-finalexams/3960567/

de Lange, C. (2016). How can I nap like a pro? New Scientist, 230(3075), 38-39. 
NAPS AND SLEEP DEPRIVATION

Dement, W. (1997, September). What all undergraduates should know about how their sleeping lives affect their waking lives. Sleepless at Stanford. Retrieved from https://web.stanford.edu/ dement/sleepless.html

Dement, W. C., \& Vaughan, C. (1999). The promise of sleep: A pioneer in sleep medicine explores the vital connection between health, happiness, and a good night's sleep. New York: Dell Trade Paperback.

Dhand, R., \& Sohal, H. (2006). Good sleep, bad sleep! The role of daytime naps in healthy adults. Current Opinion in Pulmonary Medicine, 12(6), 379-382.

Draplin, D. (2014, September 10). University Swaps Library's Study Tables For $\$ 10,000$ Napping Pod. Retrieved June 21, 2017, from http://www.thecollegefix.com/post/19199/

Drowsy driving: Asleep at the wheel. (2015). Centers for Disease Control and Prevention. Retrieved from https://www.cdc.gov/features/dsdrowsydriving/

Durrant, S. (2015, May 21). Sleeping pods for students: Can naps replace a good night's sleep? The Guardian. Retrieved from http://www.theguardian.com/higher-educationnetwork/2015/may/21/sleeping-pods-for-students-can-naps-replace-a-good-nights-sleep 
NAPS AND SLEEP DEPRIVATION

Federal Motor Carrier Safety Administration. (2014, February 19). Drowsy Driving Quiz. Retrieved March 23, 2017, from https://www.fmcsa.dot.gov/driver-safety/sleepapnea/drowsy-driving-quiz

Gilbert, S. P., \& Weaver, C. C. (2010). Sleep quality and academic performance in university students: A wake-up call for college psychologists. Journal of College Student Psychotherapy, 24(4), 295-306. doi:10.1080/87568225.2010.509245

Goretzki, M., \& Zysk, A. A. (2017). Using mindfulness techniques to improve student wellbeing and academic performance for university students: A pilot study. Journal of The Australian \& New Zealand Student Services Association, (49), 26-35.

Harvard University. (2016, May 11). Asleep at the wheel: Drowsy driving and public health. Retrieved July 28, 2017, from https://www.youtube.com/watch?v=2s21LB4uYiI

Health Education and Promotion. (2015, October 28). The UC Davis nap map. Retrieved July 28,2017 , from https://www.google.com/maps/d/viewer?mid=1P2e04qVbgII4bDQPpFawDc7hhjQ\&ie= $\underline{\mathrm{UTF} 8 \& \mathrm{hl}=\mathrm{en} \& \mathrm{msa}=0 \& \mathrm{z}=16 \& \mathrm{l}=38.54751899257417 \% 2 \mathrm{C}-121.7554505}$

Healthyhorns University Health Services. (2016). Napping. Retrieved July 28, 2017, from https://healthyhorns.utexas.edu/HT/HT_napping.html

Hemp, P. (2004). Presenteeism: at work--but out of it. Harvard Business Review, 82(10), 49. 
NAPS AND SLEEP DEPRIVATION

Herrmann, U. S., Hess, C. W., Guggisberg, A. G., Roth, C., Gugger, M., \& Mathis, J. (2010). Sleepiness is not always perceived before falling asleep in healthy, sleep-deprived subjects. Sleep Medicine, 11(8), 747-751. doi:10.1016/j.sleep.2010.03.015

Hunter, M. (2016, December 5). Students at top university vote overwhelmingly to spend $£ 40,000$ on 'ridiculous' Google-style 'nap pods' in case they find themselves dropping off in the library. Retrieved from http://www.dailymail.co.uk/news/article4001978/Students-university-vote-overwhelmingly-spend-40-000-ridiculous-Googlestyle-nap-pods-case-dropping-library.html

Jalongo, M. R., \& McDevitt, T. (2015). Therapy dogs in academic libraries: A way to foster student engagement and mitigate self-reported stress during finals. Public Services Quarterly, 11(4), 254-269. doi:10.1080/15228959.2015.1084904

Jonsson P. (2015, March 7). After daylight saving time shift, beware of 'microsleeps'. Christian Science Monitor. p. N.PAG.

Katz, J. (2016, February 26). The big dogs on campus: welcoming two new therapy dogs. Retrieved July 25, 2017, from http://themacweekly.com/2016/02/the-big-dogs-oncampus-welcoming-two-new-therapy-dogs/ 
NAPS AND SLEEP DEPRIVATION

Kryger, M. (2017). The mystery of sleep: Why a good night's rest is vital to a better, healthier life. New Haven: Yale University Press.

Lahl, O., Wispel, C., Willigens, B., \& Pietrowsky, R. (2008). An ultra short episode of sleep is sufficient to promote declarative memory performance. Journal of Sleep Research, 17(1), 3-10. doi:10.1111/j.1365-2869.2008.00622.x

Lannon, A., \& Harrison, P. (2015). Take a paws: Fostering student wellness with a therapy dog program at your university library. Public Services Quarterly, 11(1), 13-22. doi:10.1080/15228959.2014.984264

Lau, H., Alger, S. E., \& Fishbein, W. (2011). Relational memory: A daytime nap facilitates the abstraction of general concepts. Plos ONE, 6(11), 1-6. doi:10.1371/journal.pone.0027139

M. Z. (2016). Coloring books, comfort dogs and more help students shed stress. University Business, 19(1), 18.

Macalester College. (2017). Give your grades 20 minutes. Retrieved July 28, 2017, from https://www.macalester.edu/healthandwellness/healthpromotion/sleepdreams/nappingplaces.html

Mawhinney, S. (2011). Dogs provide stress (and comic) relief. AALL Spectrum, 16(2), 6-8. 
NAPS AND SLEEP DEPRIVATION

Mednick, S. C., \& Drummond, S. A. (2009). Napping. In R. Stickgold \& M. Walker (Eds.), The neuroscience of sleep (pp. 254-259). San Diego, CA, US: Elsevier Academic Press.

Mednick, S., \& Ehrman, M. (2006). Take a nap! : Change your life. New York, NY: Workman Pub.

Mednick, S., Nakayama, K., \& Stickgold, R. (2003). Sleep-dependent learning: a nap is as good as a night. Nature Neuroscience, 6(7), 697.

National Institute of Neurological Disorders and Stroke. (2008, January). Brain basics: Understanding sleep. Retrieved May 01, 2017, from https://www.ninds.nih.gov/Disorders/Patient-Caregiver-Education/Understanding-Sleep. Pub ID: 08-3440-C

National Day Calendar. (2017, March 10). National Napping Day - Day after return of Daylight Saving Time. Retrieved May 10, 2017, from https://www.nationaldaycalendar.com/national-napping-day-day-after-return-of-daylightsaving-time/

National Day Calendar. (2017, February 24). National Public Sleeping Day - February 28. Retrieved June 28, 2017, from http://www.nationaldaycalendar.com/national-publicsleeping-day-february-28/ 
NAPS AND SLEEP DEPRIVATION

Newton, D. (2011). Releasing steam: Stressbusters to market the library as place. Public Services Quarterly, 7(3/4), 169-172. doi:10.1080/15228959.2011.622648

O'Callaghan, T. (2016). What makes for a good night's rest? New Scientist, 230(3075), 36-37.

O'Connell, E. (2016, December 7). Sleeping area could come to Main Library. Retrieved July 03, 2017, from http://www.wildcat.arizona.edu/article/2016/12/sleeping-area-could-come-tomain-library

Payne, J. D., Kensinger, E. A., Wamsley, E. J., Spreng, R. N., Alger, S. E., Gibler, K., \& ... Stickgold, R. (2015). Napping and the selective consolidation of negative aspects of scenes. Emotion, 15(2), 176-186. doi:10.1037/a0038683

Peel, J. M. (2004). The labyrinth: An innovative therapeutic tool for problem solving or achieving mental focus. The Family Journal, 12(3), 287-291. doi:10.1177/1066480704264349

Pizza, F., Contardi, S., Antognini, A. B., Zagoraiou, M., Borrotti, M., Mostacci, B., \& ... Cirignotta, F. (2010). Sleep quality and motor vehicle crashes in adolescents. Journal of Clinical Sleep Medicine: JCSM: Official Publication Of The American Academy Of Sleep Medicine, 6(1), 41-45.

Pope, J. (2012). More slumber time means better performance in class. Community College Week, 25(3), 10. 
NAPS AND SLEEP DEPRIVATION

Poudel, G. R., Innes, C. H., Bones, P. J., Watts, R., \& Jones, R. D. (2014). Losing the struggle to stay awake: Divergent thalamic and cortical activity during microsleeps. Human Brain Mapping, 35(1), 257-269. doi:10.1002/hbm.22178

Reynolds, J. A., \& Rabschutz, L. (2011). Studying for exams just got more relaxing - Animalassisted activities at the University of Connecticut Library. College \& Undergraduate Libraries, 18(4), 359-367. Doi:10.1080/10691316.2011.624934

Rice, A. (2011, November 25). Bleary-eyed students can’t stop texting, even to sleep, a researcher finds. Chronicle of Higher Education. p. A13.

Robinson, T. E. \& Clark, A. C. R. (2015). From stress-relieving kittens to free coffee \& chocolate: The Whitworth University Library is market fresh. Alki, 31(2), 13-15.

Rolston, E., Sandlin, Jr, Sandlin, M., \& Keathley, R. (2007). Power napping: Effects on cognitive ability and stress levels among college students. Research Quarterly for Exercise and Sport, 78(1), A36.

Ruch, S., Markes, O., Duss, S. B., Oppliger, D., Reber, T. P., Koenig, T., \& ... Henke, K. (2012). Sleep stage II contributes to the consolidation of declarative memories. Neuropsychologia, 50(10), 2389-2396. doi:10.1016/j.neuropsychologia.2012.06.008

Sayej, N. (2016, May 4). Sleep pods, luxury recliners and nap nooks pepper campuses. Retrieved July 03, 2017, from http://www.seattletimes.com/nwshowcase/advance-course/sleeppods-luxury-recliners-and-nap-nooks-pepper-campuses/ 
NAPS AND SLEEP DEPRIVATION

Sewani, M. (2013, May 1). The Nap Map. Flyby. Retrieved July 28, 2017, from https://www.thecrimson.com/flyby/article/2013/4/27/nap_space_map/

Staff, C. R. (2011, April 25). Depression Screening Quiz: The Goldberg Depression Questionnaire. Retrieved June 29, 2017, from http://counsellingresource.com/quizzes/depression-testing/goldberg-depression/

Stutts, J. C., Wilkins, J. W., \& Vaughn, B. V. (1999, November). Why Do People Have Drowsy Driving Crashes? Input from Drivers Who Just Did. Retrieved June 22, 2017, from https://www.aaafoundation.org/why-do-people-have-drowsy-driving-crashes-inputdrivers-who-just-did

Taub, J. M., Tanguay, P. E., \& Clarkson, D. (1976). Effects of daytime naps on performance and mood in a college student population. Journal of Abnormal Psychology, 85(2), 210-217. doi:10.1037/0021-843X.85.2.210

Tucker, M. A., Hirota, Y., Wamsley, E.J., Lau, H., Chaklader, A., \& Fishbein, W. (2006). A daytime nap containing solely non-REM sleep enhances declarative but not procedural memory. Neurobiology of Learning and Memory, 86(2), 241-247. 
NAPS AND SLEEP DEPRIVATION

Tulane University nap map. (n.d.). Retrieved July 28, 2017, from https://www.google.com/maps/d/viewer?mid=1BQNPr0lybRCfDBRWfZXQNrQsDN0\& $\underline{\mathrm{hl}=\mathrm{en} \_U S \& l l=29.938180034159895 \% 2 \mathrm{C}-90.12169809934073 \& \mathrm{z}=17}$

UCSD Student Health Advocate Program. (2011). The Triton nap guide. Retrieved July 28, 2017, from http://sha.ucsd.edu/nap

University of East Anglia. (n.d.). What's the Nap Nook? Retrieved July 26, 2017, from https://www.uea.ac.uk/study/undergraduate/advice/ask/campus/what-s-the-nap-nook

University of Manchester. (n.d.). Zzz zone. Retrieved July 03, 2017, from http://www.library.manchester.ac.uk/locations-and-opening-hours/learningcommons/zzz-zone/

University of Pittsburgh University Marketing Communications Webteam. (2012, June 19). PSQI. Retrieved June 29, 2017, from http://www.psychiatry.pitt.edu/node/8240

URWell. (n.d.). Nap map. Retrieved July 28, 2017, from http://wellness.richmond.edu/offices/healthcenter/nap-map.html

Wagner, U., \& Born, J. (2008). Memory consolidation during sleep: Interactive effects of sleep stages and HPA regulation. Stress: The International Journal on the Biology of Stress, 11(1), 28-41. doi:10.1080/10253890701408822 
NAPS AND SLEEP DEPRIVATION

Wagner, U., Hallschmid, M., Rasch, B., \& Born, J. (2006). Brief sleep after learning keeps emotional memories alive for years. Biological Psychiatry, 60(7), 788-790. doi:10.1016/j.biopsych.2006.03.061

Wake Forest University (n.d.). ZieSta Room. Retrieved July 03, 2017, from https://zsr.wfu.edu/about/spaces/ziesta-room/

Washington State University. (n.d.). Retrieved June 29, 2017, from https://chinook.wsu.edu/facilities/nap-zone/

Watson, N. F., Morgenthaler, T., Chervin, R., Carden, K., Kirsch, D., Kristo, D., ... Wise, M. (2015). Confronting drowsy driving: The American Academy of Sleep Medicine perspective. Journal of Clinical Sleep Medicine: JCSM: Official Publication of The American Academy of Sleep Medicine, 11(11), 1335-1336. doi:10.5664/jcsm.5200

Wasielewski, A. (2009). The huge hubbub. College \& Research Libraries News, 70(7), 394-396.

WebMD Medical Reference. (2016, October 16). What are REM and non-REM sleep? Retrieved May 02, 2017, from http://www.webmd.com/sleep-disorders/guide/sleep-101 


\section{NAPS AND SLEEP DEPRIVATION}

Williams, L. R., Davies, D. R., Thiele, K., Davidson, J. R., \& MacLean, A. W. (2012). Young drivers' perceptions of culpability of sleep-deprived versus drinking drivers. Journal of Safety Research, 43(2), 115-122. doi:10.1016/j.jsr.2012.02.002

Wolf-Meyer, M. (2013). Where have all our naps gone? or Nathaniel Kleitman, the consolidation of sleep, and the historiography of emergence. Anthropology of Consciousness, 24(2), 96116. doi:10.1111/anoc. 12014

Ye, L., Hutton Johnson, S., Keane, K., Manasia, M., \& Gregas, M. (2015). Napping in college students and its relationship with nighttime sleep. Journal of American College Health, 63(2), 88-97. doi:10.1080/07448481.2014.983926

Zhang, G., Sun, F., \& Liao, J. (2009). The effects of lunch time napping on habitual nappers' mental work efficiency in the afternoon and early. Health, 01(04), 284-289.

Zielonka, A. (2016, December 5). A napping center could be coming to the University of Maryland thanks to an SGA proposal. Retrieved from http://www.dbknews.com/2016/12/06/university-of-maryland-sga-napping-center/

Zucker, D. M., Choi, J., Cook, M. N., \& Croft, J. B. (2016). The effects of labyrinth walking in an academic library. Journal of Library Administration, 56(8), 957-973. doi:10.1080/01930826.2016.1180873 